Historic, Archive Document

Do not assume content reflects current scientific knowledge, policies, or practices. 

SINGLE PEONIES

\begin{tabular}{|c|c|c|c|c|}
\hline & & & & \\
\hline & Small & Good & Large & 1 \\
\hline & & Div. & Div & Year \\
\hline x Albiflora, The Bride & & 1.00 & 1.50 & \\
\hline * Albiflora, Carnea & & .50 & 1.00 & \\
\hline * Anamola Smouthii & & 1.00 & 1.50 & 2.00 \\
\hline x Avant Garde & 2.00 & 3.00 & 4.00 & 5.00 \\
\hline * Defiance -.--------- & & 1.00 & 1.25 & 2.00 \\
\hline *The Moore & & 1.00 & 1.50 & 2.00 \\
\hline * L'Etincelante & 1.00 & 2.00 & 2.50 & \\
\hline Le Jour & 1.00 & 2.00 & 2.50 & \\
\hline Minnehaha & & 2.00 & 2.50 & \\
\hline Nellie & 1.00 & 2.00 & 3.00 & \\
\hline$x$ Pride of Langport & 3.00 & 5.00 & 6.00 & \\
\hline * Splendens & & 1.00 & 1.50 & 2.00 \\
\hline
\end{tabular}

* varieties can be selected for discount

Good divisions of low and moderate priced will weigh $1 / 2 \mathrm{lb}$. and over. except noted.

Large divisions of low and moderate priced will weigh $1 / 2 \mathrm{lb}$. and over except noted.

Rebate does not apply on $\mathrm{X}$ sorts.

$\mathrm{X}$ sorts will be under weight and no refund.

JAP PEONIES

Small Good Large 1

Alma

* Attraction -

$2.00 \quad 2.50 \% / 8 \mathrm{lb}$.

x Dawn -

$x$ Esther -

x X Mikado --

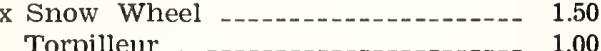

Torpilleur

Philomele .

$\begin{array}{ll}1.00 & 1.50 \\ 2.00 & 3.00 \% / 2\end{array}$

$\begin{array}{ll}2.00 & 3.00 \\ 1.00 & 1.25\end{array}$

$2.00 \mathrm{~T} / 4 \mathrm{lb} .2 .50 \mathrm{~m} / \mathrm{s}$

$2.00^{1 / 4} \quad 3.003 / 8$

$2.00 \frac{1}{4} \quad 3.00 \%$

$1.00 \quad 1.25$

$.75 \quad 1.25$

$\begin{array}{rr}.75 & 1.25 \\ 5.00 & 8.00\end{array}$

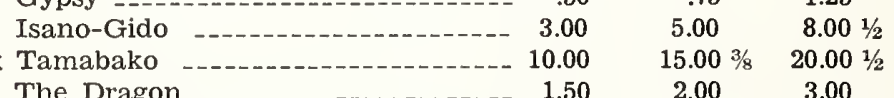

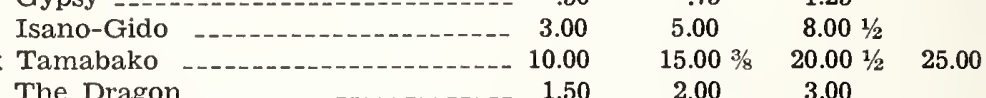

The Dragon --1.-- 1.50

* varieties can be selected for discount or rebate applied toward purchase. Rebate does not apply on $\mathrm{x}$ sorts.

Good divisions of low cost sorts will weigh $3 / 8$ to $1 / 2 \mathrm{lb}$. and up.

Large divisions of low cost sorts will weigh $1 / 2$ to $3 / 4 \mathrm{lbs}$. and over.

\section{SINGLE PEONIES}

It is the plain and simple things that are more beautiful and flower lovers who contend that the singles and Japs are the most beautiful have a very good chance of winning out. To be on the winning side include two or three single or Japanese with every dozen.

Albiflora, The Bridle-Finest single white. Blooms so early it is available on Memorial Day. Indispensible.

Anamola Smouthii-Fine bright red. The flrst Peony to bloom and for this reason prized by all who possess it. This Peony is much superior to Tenefolia, having longer stems, flowers last longer and foliage stays green all summer, whie Tenefolia soon dries up like an Oriental Poppy.

Defiance-Fine large showy flowers between red and pink.

The Moore-Way underrated. Fine dark red almost as dark as Cahuzac. The very best low priced single.

Minnehaha-Fine large early bright red.

L'Etincelante-Carmine pink, pronounced silver edge. Large flowers. One of the very finest singles.

Pride of Langport-Bright peach pink. Extra fine, finest pink single.

Pride of Langport-Bright peach pink. Extra fine,
Nellie-Large flower, light pink of beautiful shade.

Splendens.-(Keway) large flower of great substance. The nearest scarlet single Peony. Better than Mafeking.

\section{JAPS}

Alma-Delicate pink, large bunch of petaloides. Fine.

Esther-Pink guards, white center tipped rose. Very dainty and as fine as some much higher in price.

snow Wheel-Second finest white Jap. Small rooted. Pay enough and secure larger root.

Torpilleur-Next to Mikado the finest red Jap, but so distinct that it is unlike it. Roots are smaller than average. Pay more for a larger root.

Philomele-Pink guards with center of almost orange yellow. Large flower, honey fragrance. A fine and finer than some higher in prices. Attraction-Well named. Large flower of clear mauve rose pink. Fine. Aetice Renee-Large flower of clear mauve pink. Way underrated. Some years I would rate it 85 or more. The very best low priced
some pink Jap.

The PDrazon-Large fine dark red. Distinct.

Minadio-One of the very best red Japs. Mine is the largest flowered variety.

Tamabako-As fine among the pink Japs as Langport is of the singles. Utmost.

Gypsy-Large very dark red that pleases beginners. Not as fine as Mikado but a good buy.

\section{SYMPOSIUMS}

Ratings in the Peony symposiums are much better than the Iris symposiums and yet of not much value to beginners unless guided by symposiums and yet of

TUE LAST SYMPOSIUM

Such a mess was made in rating that the Judges names were kept secret. More experienced growers would have remembered from other years the higher quality of Phyllis Kelway, Lord IKitchener, Petite Renee, The Moore and others. Rely on Friry Gardens Ratings.

More Evidence

"The last several years I have been the recipient from you of some Peonies and Irises that have done well. I particularly value your ratings; a light in the wilderness, I might almost say. The Peony Symposium is of some value as indicating the worth of those varieties generally well known; but, from my experience of certain arelies I am franty celtain

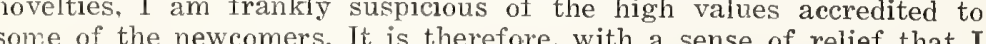
turn to you that I turn to your modest list, where you have set your own modest appraisal of the varieties you offer." 


\section{BARGAINS}

Asa Gray

Good

Div.

Large

1

D. D. Nemour's

.35

Div

Year

Duchess of Portland, sing.

Eugene Bigot

Glorie Chas. Gumbault _....................

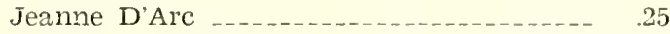

.50

Stanley, single red

Rosy Dawn (Barr)

.50

C. D. Orr

.35

. .75

.50

1.00

Mad Augusta Dessert

.50

.75

.75

.50

Mine. B. Des Champs

All will be of fair veight count.

Note-Rebate does not apply on bargains and none given for dis-

\section{SOFIETHNG FOR NOTHING}

$1,2,3$, or more of the above will be given free with ol'da's of $\$ 2.50$ and up. Number given and size will depend somewhat on o:der. Name a list to select from, and indicate prefelence. Be economical with postage, receive an economical root. rirst buyers have first chance. No trash in bargain list. Go to it. Get all you can for nothing! ! !

\section{SOME GOAT}

Peony Goats are worse off than others because it takes several years to find out they were one all this time. Avoid beirg a goat by not falling for bargain Peony collections. How easy it would be for me to list my bargains at abnormal prices and then get away with it by cutting the price in two for the entire herd.

\section{MY PQNY GOATS}

Are better than other's because of their low price. 



\section{Some Descriptions}

You can rely upon Fairy Garden Descriptions EXTRA CHOICE WHITES

It would be wisdom for beginners and others to let Le Cygne wait and buy such extra choice whites as Alsace Lorraine, Nymphae and Francis Willard and buy these in one year. Yóu can secure all three for the price of Le Cygne.

\section{LAST WHITE}

Marie Lemoine - is the best investment for bloom and money saved. Buds do not open every year on every plant. Its low price allows buying more one year plants to make more certain bloom and money will be left over. Instead of buying the unreliable Mirelle or Entchantresse.

\section{LAST PINK}

Grandiflora-As fine among the late pinks as Therese is among the earlies. All buds do not open every year, but low price allows buying more than one one ycar plant. Galathea nearest rival, extra fine, but hardly as choice.

Glorious-is well named. I think the finest white. Sometimes a slow grower for a few years. Certainly a treasure. The utmost Peony. Lord Kitchener-Should rate over 85 for its season. Beginners with limited funds will be wise to buy L. K. in preference to R. C. and buy a one year, get bloom while they are living and have some money left to buy more Peonies. L. K. has every quality of R. C. except length of stems. Blooms young free bloomer. Side buds open giving a long season. Color is very distinct from R. C. a bright cherry of dazzling hue.

Cahuzac-Rather extreme color, but very desirable for variety.

M. J. Dessert-Worthy of its high rating. One of the very finest.

M. J. Dessert-Worthy of its high rating. One of the very finest.
Georgiana Shaylor-Pale rose pink, extra choice.

Philip Revoir-The utmost red Peony

Adolph Roussau-Best very dark, very early red.

Walter Faxon-A great Peony that everyone must have.

\section{BRAND PEONIES}

Brand red Peonies are synonomous with brightness and I have discarded other reds in their favor. The reds in my list are all so brilliant, yet distinct that one cannot stop with one b,ut must have two or three or all.

Chas. McKellip-Choice velvety red.

Longfellow-Brightest of all red Peonies.

Lora Dexheimer-is close to Longfellow in brightness.

Richard Carvel-Earliest darker red.

Winnefred Domme-Vies with Longfellow in brightness, but very distinct, a clear dark scarlet. Medium stem and flower, but its color tinct, a clear dark scarlet. Medium stem and flower, but its color
is so intense that it fairly glows, shimmers and scintilates. The is so intense that
best dwarf red.

Chestine Gowdy-Should rate close to 93. Brands low priced Peony. Peaches and cream with a cherry in the middle. A charmer, a sweet thing?

\section{SPECIFICATIONS}

\section{SMALL DIVISIONS}

Mine are as large as any grower sends out, having one or two eyes. No split or chopped off roots. Supply limited.

\section{GOOD DIVISIONS}

Are larger than small and as large as some call standard divisions. $1,2,3,4$ eyes. Some bloom but do not expect it.

\section{LARGE DIVISIONS}

This grade is still larger and is a selection from the natural divisions remaining after a Peony clump has been divided. 2, 3, 5or more strong eyes with well balanced root systems. Some will bloom but it is not generally expected.

\section{ONE YEAR PLANTS}

Are the happy medium and the best for general planting because they can reasonably be expected to bloom. My one year Peony plants are all of what the name implies, being a large division that has been grown a year and have two, three or more strong stems of this years growth. Prices quoted on one year on varieties not priced.

\section{TWO YEAR PEONES}

It is possible to secure two year Peony plants that are healthy. These It is possible to secure two year Peony plants that
will give more flowers the first year. Prices quoted.

\section{ACCORDING TO VARIETY}

No grower can guarantee an equal number of eyes, stems and weight or every variety of a given size or grade because some Peonies are small rooted, others have few eyes. Most few eyed varieties are large rooted and a large root you will get to make up for less eyes and stems if purchased from Fairy Gardens.

$$
\text { GUARANTEE }
$$

I guarantee the weight of all varieties listed except where noted.

$$
\text { IT IS UNDERSTOOD }
$$

If a root falls short in weight that this lack can be made up on another variety.

$$
\text { AGAIN UNDERSTOOD }
$$

If the money value is not made up on less cost sorts a refund will be forthcoming.

To make up for lack of weight I will not send you an Iris or other plant but return the rmoney your have coming.

plant but return the money you have coming.
WHICH SIZ T T T

By all means buy as large sizes as can be afiorded and then some. If possible purchase one year plants, at least of low cost kinds. If one year size cannot be afforded then plant large divisions.

\section{WIERCH VARIETIES TO BUY}

If a beginner buy largely from my unassailable list. If money is no object buy one each and some more of the very choicest and then rely on Fairy Garden service to pick the very best for the money from other lists.

Life is too short to waste on waiting two or three years for small Peony divisions to grow to blooming size. The money saved on more expensive varieties may justify waiting, but on low or moderate price expensive val
kinds, never? 


\section{SAID IT FIRST}

Some years ago I revolutionized the system of describing Irises by issuing a catalog with frank descriptions.

\section{NOTHER REVOLT}

The present method of grading Peony divisions is often not satisfactory to grower or buyer. The right way is to specify the weight and then everyone will know exactly how much root they will get.

$$
\text { MY SYSTEM }
$$

Until improved is the fairest to buyer and seller. Overweight canne expected and underweight must be made good.

\section{THE WEIGHT}

Cannot be the same for low and higher priced varieties, small rooted and few eyed Peonies. It is up to The Growers Association to set a standard of weight for standard Peony divisions and then everyone will know where they are at.

WHAT COUNTS

It is the size of the eyes and the weight and condition of the root. YOUNG BLOOMERS

Select these in one or two year sizes and you will be sure of bloom the first year and naturally the larger the plant the more bloom.

\section{NONE FIRST YEAR BLOOMERS}

Buy one year size and when they do commence blooming there will be more floxers because of being one year stronger, they will be that far be more
ahead.

TWIN ROOTS

One year twins will not bloom. My one and two year roots are selected compact all together roots with strong blooming eyes that will give results.

$$
\begin{gathered}
\text { More Varieties } \\
\text { Can be supplied. Write if interested. }
\end{gathered}
$$

$$
\text { DISCOUNT }
$$

Orders $\$ 5$ and up have a rebate of $10 \mathrm{c}$ coming on every dollar remitted, to be applied on the purchase of any other variety except those varieties excepted.

Rebate does not apply on small divisions less than $\$ 1.50$ and only some small divisions can be selected for rebate.

\section{NOTE AGAIN}

That discount applies on some varieties that cannot be selected for premium

Again. Purchase price can be made up in cash if rebate does not cover.

In planting Peonies you plant for permanency-therefore select with great care varieties of unquestioned quality and value, purchase Inrger roots of these, and let the doubtful sorts wait until you have absolute proof of their worth.

$$
\text { The Quality of my stock. }
$$

The roots I send out are second to none. All divisions are from plants not over three years old. This assures all new growth, sound and healthy. Not old stuff pitted with decay. All roots are intelligently prepared for immediate planting. All have been cleaned, so half the roots will not be lost because rotten portions must be cut out.

$$
\text { TIMIE TO PLANT }
$$

It is not too late to plant Peonies, even if freezing threatens. Frozen ground will thaw again. Cover ground with leaves, trash, straw, boards, etc. and plant way into December, or store in boxes of soil until spring.

\section{SPRING PLANTING}

Every spring I plant left over roots from fall and expensive sorts from boxes kept on the north side of a building to keep them dormant. They will stay dormant until early May, this insures customers securing Peony roots not advanced in growth.

\section{RESERVATIONS}

A deposit on orders of $\$ 5.00$ and up will reserve roots until shipment is desired including next spring. If ground will not be ready until spring or not convenient to pay until then. Reserve some roots and gain a season's growth.

I was growing Peonies years before some present day growers knew what a Peony looked like. Hundreds of varieties have been discarded, some of which are still being foisted off on a confiding public.

$$
\text { BEGINNERS }
$$

Who rely upon Fairy Garden selections will secure Peonies that never will become obsolete. My collection has been refined every year and this season gave it the once over.

\section{QUANTITY QUOTATION}

3 or more of a variety of the same size will be quoted.

$$
\text { POSTAGE }
$$

Your Postmastèr will tell which zone to use. Divisions of expensive and moderate price, 1 st, 2 nd zone $10 \mathrm{c}$ : $3 \mathrm{rd}$ and 4 th zone, $15 \mathrm{c} ; 5$ th and 6 th zone, $20 \mathrm{c}$.

Large divisions of cheap sorts and 1 year expensive. 1 nad 2 nd zone $15 \mathrm{c}$; 3rd and 4th zone, 20c; 5th and 6th zone, $25 \mathrm{c}$

The above rates are for one root. Add $3 c, 5 c$ and $10 \mathrm{c}$ additional small or good division. Large or one year. Heavy shipments are best shipped by express.

$$
\text { C. O. D. }
$$

If postage is not remitted, shipments will go C. O. D. collect for postage and $5 \mathrm{c}$ for fee. All orders are accepted on these terms.

I never have substituted. Guarantee

sill made

Insurance

5c Shipments invariably arrive. Save a nickle.

$$
\text { Terms }
$$

Cash or satisfactory reference. No credit orders less than $\$ 15.00$. Payments should be made to H. W. Groschner. Ohio.

Address either Fairy Gardens or H. W. Groschner, Napoleon, 0. 